\title{
Comparative Study to Evaluate Safety and Efficacy of Sitagliptin Versus Metformin Alone and Combination in Type 2 Diabetes Mellitus
}

\author{
Dr. Naveed Altaf ${ }^{1}$, Dr. Mirza Arshad Asif Baig ${ }^{2 *}$ \\ ${ }^{1}$ Associate Professor, Shadan Institute of Medical Sciences Teaching Hospital \& Research Center, Hyderabad \\ ${ }^{2}$ Assistant Professor, Dr. VRK Women's Medical College Teaching Hospital \& Research Center, Aziznagar, Moinabad
}

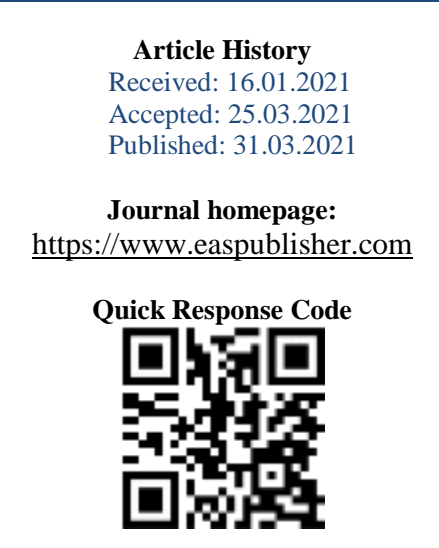

\begin{abstract}
Introduction: Type 2 Diabetes mellitus is characterized by high blood glucose, insulin resistance, and relative lack of insulin. Common symptoms include increased thirst, frequent urination, and unexplained weight loss. Material and Methods: This is a Prospective, Comparative, Randomized and Parallel group study. Study was conducted in Type 2DM patients attending the outpatient department of Medicine in tertiary care center. Group I received Metformin $500 \mathrm{mg}$ BD for 3 months, Group II received Sitagliptin $50 \mathrm{mg}$ BD for 3 months and Group III Metformin $500 \mathrm{mg}$ BD and Sitagliptin 50mg BD for 3 months. Result: The mean fasting blood glucose level in Group I at baseline was $143.14 \pm 5.38 \mathrm{mg} / \mathrm{dl}$ and after 3 months was $93.85 \mathrm{mg} / \mathrm{dl}$, in Group II was $147.15 \pm 5.38 \mathrm{mg} / \mathrm{dl}$ and after 3 months $91.47 \pm 4.20 \mathrm{mg} / \mathrm{dl}$ and in Group III was $145.23 \pm 5.47 \mathrm{mg} / \mathrm{dl}$ and after 3 months $87.47 \pm 4.27 \mathrm{mg} / \mathrm{dl}$. The mean of PPBG level in Group I was $194.23 \pm 14.58 \mathrm{mg} / \mathrm{dl}$ at baseline, followed by $152.68 \pm 9.24 \mathrm{mg} / \mathrm{dl}$ after $3^{\text {rd }}$ month. In Group II the mean of PPBG level was $197.79 \pm 14.52 \mathrm{mg} / \mathrm{dl}$ at baseline followed by $131.47 \pm 8.63 \mathrm{mg} / \mathrm{dl}$ after $3^{\text {rd }}$ month. In Group III the mean of PPBG level was $196.64 \pm 13.63 \mathrm{mg} / \mathrm{dl}$ at baseline followed by $127.74 \pm 9.37 \mathrm{mg} / \mathrm{dl}$ after $3^{\text {rd }}$ month. Conclusion: Both sitagliptin or metformin monotherapy helped in improving glycemic control in patients with type 2 diabetes mellitus. Both the group of the drugs was well tolerated by the patients. The result of this study provides the data for the use of sitagliptin as initial monotherapy for type 2 diabetes mellitus patients.
\end{abstract}

Keywords: Type 2 Diabetes Mellitus, Sitagliptin, Metformin, Blood Glucose.

Copyright (C) 2021 The Author(s): This is an open-access article distributed under the terms of the Creative Commons Attribution 4.0 International License (CC BY-NC 4.0) which permits unrestricted use, distribution, and reproduction in any medium for non-commercial use provided the original author and source are credited.

\section{INTRODUCTION}

Type 2 Diabetes mellitus is characterized by high blood glucose, insulin resistance, and relative lack of insulin. Common symptoms include increased thirst, frequent urination, and unexplained weight loss [1]. Symptoms may also include increased hunger, feeling tired, and sores that do not heal. Often symptoms come on slowly. Long-term complications from high blood sugar include heart disease, strokes, diabetic retinopathy which can result in blindness, kidney failure, and poor blood flow in the limbs which may lead to amputations [2].

The prevalence of DM has shown a dramatic rise over the past 200 years. It is estimated that in 2017 , there were 451 million people (ages 18-99 years) with diabetes worldwide, and this number is expected to rise, mostly due to type 2 DM. Prevalence of Diabetes in India according to International Diabetes Federation (IDF) in 2017, more than 61.3 million Indians are currently suffering from diabetes i.e. more than $8 \%$ [3].
Monotherapy with Metformin, a biguanide agent acts primarily as an insulin sensitizer. Its primary clinical site of action is in the liver, improving hepatic insulin sensitivity and as a result, decreasing hepatic gluconeogenesis. Metformin may also increase both hepatic and splanchnic glucose utilization. Metformin also has significant effects on peripheral insulin sensitivity, primarily at muscle and modestly at adipocyte by phosphorylation and activation of AMPactivated protein kinase [4].

Sitagliptin is an oral, highly selective dipeptidyl peptidase-4 (DPP-4) inhibitor for the treatment of patients with Type 2 Diabetes Mellitus. Sitagliptin inhibits the enzymatic degradation and inactivation of glucagon-like peptide-1 (GLP-1) and glucose dependent insulinotropic peptide (GIP) by DPP-4 the major incretins involved in glucose homeostasis, thereby increasing insulin release and lowering glucagon secretion in a glucose-dependent manner [5]. Treatment with sitagliptin $100 \mathrm{mg}$ once daily leads to improvements in glycaemic control in patients with Type 2 Diabetes Mellitus, including 
reductions in fasting and postprandial glucose concentrations [6]. Sitagliptin has not been associated with an increased risk of hypoglycaemia when administered as either monotherapy or in combination with agents not known to cause hypoglycaemia [7]. The combined use of sitagliptin and metformin is an effective method of lowering glucose levels in Type 2 Diabetes Mellitus and this combination had been approved by US Food and Drug Administration [8].

As with all antihyperglycaemic agent, monotherapy with metformin is often unsuccessful in achieving or maintaining adequate glycaemic control. Furthermore, patients who initially get to goal with monotherapy frequently require additional agents over time in order to maintain glycaemic control due to the progressive decline in pancreatic beta cell mass. Initial combination therapy offers an alternative approach to single-agent therapy for the treatment of Type 2 Diabetes Mellitus, especially in patients with moderateto high HbAlc levels for which the use of initial combination therapy is considered a potential treatment option supported by practice guidelines.

So, the purpose of this study was to assess the safety/tolerability and efficacy of initial therapy with the Fixed Dosed Combination of Metformin/Sitagliptin compared with Metformin and Sitagliptin monotherapy in drug-naive patients with Type 2 Diabetes Mellitus not controlled on a diet/exercise regimen.

\section{Material ANd Methods}

This is a Prospective, Comparative, Randomized, Parallel group study. Study was conducted in Type 2DM patients attending the outpatient department of Medicine in tertiary care center.

Inclusion criteria: Patients of either sex having age group between 30-60 years. Patients having newly diagnosed Type II DM with prandial blood glucose levels $>180 \mathrm{mg} \%$ and $<250 \mathrm{mg} \%$. HbAlc in the range of 6.5 to $8.5 \%$ at screening and BMI $>27 \mathrm{~kg} / \mathrm{m}^{2}$

Exclusion criteria: Presence of Type I DM, Known allergy to study drugs, Deranged liver function test or kidney function test, History of myocardial infarction or anemia. Pregnant and lactating women. Presence of gastrointestinal diseases like inflammatory bowel disease, large hernias, intestinal obstruction, active ulcers, chronic pancreatitis. Taking any other concomitant medication effecting glucose homeostasis like corticosteroids.

1. Group I received Metformin $500 \mathrm{mg}$ BD for 3 months,

2. Group II received Sitagliptin $50 \mathrm{mg}$ BD for 3 months

3. Group III Metformin $500 \mathrm{mg}$ BD and Sitagliptin 50mg BD for 3 months

\section{Statistical Analysis}

Paired, unpaired t-tests and ANOVA were used to measure the differences among the group.

\section{RESULTS}

Table-1: Comparison of Mean Age in Groups:

\begin{tabular}{|l|l|l|l|l|l|l|}
\hline \multirow{2}{*}{ Age-Group } & \multicolumn{2}{l|}{ Group I } & \multicolumn{2}{l|}{ Group II } & \multicolumn{2}{l|}{ Group III } \\
\cline { 2 - 8 } & No & Percentage & No & Percentage & No & Percentage \\
\hline$\leq 40$ year & 02 & $2.9 \%$ & 04 & $5.9 \%$ & 03 & $4.4 \%$ \\
\hline $41--50$ & 26 & $38.8 \%$ & 26 & $38.8 \%$ & 25 & $37.3 \%$ \\
\hline $51--60$ & 39 & $58.2 \%$ & 37 & $55.2 \%$ & 39 & $58.2 \%$ \\
\hline Total & 67 & 100 & 67 & 100 & 67 & 100 \\
\hline Mean \pm SD & $52.29 \pm 6.55$ years & \multicolumn{6}{|l|}{$51.10 \pm 6.62$ years } & \multicolumn{2}{l|}{$53.42 \pm 6.58$ years } \\
\hline
\end{tabular}

In Table-1, in three groups, maximum number of patients were in the age group of 51-60 years and least number of patients were $\leq 40$ years of age. Mean age in group I patients were $52.29 \pm 6.55$, in Group II patients were $51.10 \pm 6.62$ and in Group III patients were $53.42 \pm 6.58$.

Table-2: Gender difference between Group I, II and Group II

\begin{tabular}{|l|l|l|l|l|l|l|}
\hline \multirow{2}{*}{} & \multicolumn{2}{|c|}{ Group I } & \multicolumn{2}{c|}{ Group II } & \multicolumn{2}{c|}{ Group III } \\
\cline { 2 - 7 } & $\mathbf{n = 6 7}$ & $\mathbf{( \% )}$ & $\mathbf{n = 6 7}$ & $\mathbf{( \% )}$ & $\mathbf{n = 6 7}$ & $\mathbf{( \% )}$ \\
\hline Male & 43 & 64.17 & 46 & 68.65 & 44 & 65.6 \\
\hline Female & 24 & 35.83 & 21 & 31.35 & 23 & 34.3 \\
\hline Total & 67 & 100 & 67 & 100 & 67 & 100 \\
\hline
\end{tabular}

The Table- 2 reflects that 201 diabetic patients selected, in Group I: 43 were male $(64.17 \%)$ while 24 were female patients (35.83\%). In Group II consisted of
46 male patients $(68.65 \%)$ and 21 female patients $(31.35 \%)$. In Group III consisted of 44 male patients $(65.6 \%)$ and 23 female patients $(34.3 \%)$. 
Table-3: Comparison of Mean Fasting Blood Glucose level between Group I, II and Group III at baseline versus after 3 months

\begin{tabular}{|l|l|l|l|}
\hline & $\begin{array}{l}\text { Group I } \\
\text { Mean } \pm \text { SD }\end{array}$ & $\begin{array}{l}\text { Group II } \\
\text { Mean } \pm \text { SD }\end{array}$ & $\begin{array}{l}\text { Group III } \\
\text { Mean } \pm \text { SD }\end{array}$ \\
\hline Baseline & $143.14 \pm 5.38$ & $147.15 \pm 5.38$ & $145.23 \pm 5.47$ \\
\hline After 3 Months & $93.85 \pm 4.51$ & $91.47 \pm 4.20$ & $87.47 \pm 4.20$ \\
\hline p-value & $<0.0001$ & $<0.0001$ & $<0.0001$ \\
\hline
\end{tabular}

Mean \pm SD in mg/dl, SD: Standard deviation, NS: Not significant, $* \mathbf{p}<0.05$ significant, $* *$ p $<0.001$ highly significant

In Table-3, the mean fasting blood glucose level in Group I at baseline was $143.14 \mathrm{mg} / \mathrm{dl}$ with SD of $5.38 \mathrm{mg} / \mathrm{dl}$, in Group II was $147.15 \mathrm{mg} / \mathrm{dl}$ with SD of $5.38 \mathrm{mg} / \mathrm{dl}$ and in Group III was $145.23 \mathrm{mg} / \mathrm{dl}$ with SD of $5.47 \mathrm{mg} / \mathrm{dl}$. The mean fasting blood glucose level in Group I after 3 months was $93.85 \mathrm{mg} / \mathrm{dl}$ with SD of
$4.51 \mathrm{mg} / \mathrm{dl}$, in Group II was $91.47 \mathrm{mg} / \mathrm{dl}$ with SD of $4.20 \mathrm{mg} / \mathrm{dl}$ and in Group III was $87.47 \mathrm{mg} / \mathrm{dl}$ with SD of $4.27 \mathrm{mg} / \mathrm{dl}$. These was statistically highly significant difference in mean Fasting Blood Glucose level at baseline versus after 3 months in Group I, Group II and Group III $(\mathrm{p}<0.0001)$.

Table-4: Comparison of Mean Post-Prandial Blood Glucose level between Group I, II and Group III at baseline versus after 3 months:

\begin{tabular}{|l|l|l|l|}
\hline & $\begin{array}{l}\text { Group I } \\
\text { Mean } \pm \text { SD }\end{array}$ & $\begin{array}{l}\text { Group II } \\
\text { Mean } \pm \text { SD }\end{array}$ & $\begin{array}{l}\text { Group III } \\
\text { Mean } \pm \text { SD }\end{array}$ \\
\hline Baseline & $194.23 \pm 14.58$ & $197.79 \pm 14.52$ & $196.64 \pm 13.63$ \\
\hline After 3 Months & $152.68 \pm 9.24$ & $131.47 \pm 8.63$ & $127.74 \pm 9.37$ \\
\hline p-value & $<0.0001$ & $<0.0001$ & $<0.0001$ \\
\hline
\end{tabular}

In Table-4, in Group I the mean of PPBG level was $194.23 \pm 14.58 \mathrm{mg} / \mathrm{dl}$ at baseline, followed by $152.68 \pm 9.24 \mathrm{mg} / \mathrm{dl}$ after $3^{\text {rd }}$ month. In Group II the mean of PPBG level was $197.79 \pm 14.52 \mathrm{mg} / \mathrm{dl}$ at baseline followed by $131.47 \pm 8.63 \mathrm{mg} / \mathrm{dl}$ after $3^{\text {rd }}$ month. In Group III the mean of PPBG level was $196.64 \pm 13.63$ $\mathrm{mg} / \mathrm{dl}$ at baseline followed by $127.74 \pm 9.37 \mathrm{mg} / \mathrm{dl}$ after $3^{\text {rd }}$ month.

Table-5: Comparison of Mean HbA1c between Group I, Group II and Group III at baseline versus after 3 months

\begin{tabular}{|l|l|l|l|}
\hline & $\begin{array}{l}\text { Group I } \\
\text { Mean } \pm \text { SD }\end{array}$ & $\begin{array}{l}\text { Group II } \\
\text { Mean } \pm \text { SD }\end{array}$ & $\begin{array}{l}\text { Group III } \\
\text { Mean } \pm \text { SD }\end{array}$ \\
\hline Baseline & $7.54 \pm 0.73$ & $7.49 \pm 0.67$ & $7.64 \pm 0.63$ \\
\hline After 3 Months & $7.08 \pm 0.68$ & $6.47 \pm 0.53$ & $6.23 \pm 0.37$ \\
\hline p-value & $<0.0001$ & $<0.0001$ & $<0.0001$ \\
\hline
\end{tabular}

In Table-5, Group I the mean of HbA1c level was $7.54 \pm 0.73 \%$ at baseline and $7.08 \pm 0.68 \%$ after $3^{\text {rd }}$ month. In Group II the mean of $\mathrm{HbA1c}$ level was $7.49 \pm 0.67 \%$ at baseline, $7.49 \pm 0.67 \%$ after $3^{\text {rd }}$ month. In Group III the mean of HbA1c level was $7.64 \pm 0.63 \%$ at baseline and $6.23 \pm 0.37 \%$ after $3^{\text {rd }}$ month.

\section{DISCUSSION}

International Diabetes Federation (IDF) and the American Association of Clinical Endocrinologists (AACEs), suggest that HbA1c less than $6.5 \%$ is the prime target in Type 2 diabetes mellitus patients and it is proved that good glycemic control helps in reduction of the macrovascular and microvascular complications [9].

Metformin lowers hepatic glucose output and it also increases hepatic sensitivity to insulin and decreases hepatic gluconeogenic substrates which results in decreasing gluconeogenesis. In addition, it also helps in increased utilization and uptake of glucose by skeletal muscles. And also reduces glycogenolysis. Apart from glycemic control it also has a potential to induce mild anorexia, which may facilitate glycemic control. Metformin is eliminated by renal tubular secretion, and it half-life is 6.2 hours [10].

Sitagliptin is highly selective DPP-4 inhibitor, its Oral bioavailability is nearly $87 \%$ and terminal halflife is about 10 to 12 hours. Bloomgarden et al., have shown that different oral antihyperglycaemic agents have similar efficacy when the data are corrected for differences in baseline HbA1c values [11]. Our study has shown that patient with sitagliptin were having lesser side effect and better tolerated, apart from achieving better glycemic control hence it can be used apart from metformin as initial therapy. Brazg et al., has done A randomized, double-blind, placebo controlled study for evaluation of sitagliptin and metformin combination and its impact on glycemic levels [12]. It was shown that patients on combination had better 
glycemic reduction than compared to placebo group [13]. Williams-Herman et al. has done a longer-term randomized control trails to establish the safety and efficacy of sitagliptin/metformin in type-2 diabetes patients with poor glycemic control [14].

It was shown that Sitagliptin and metformin combination group was having greater HBa1c Reduction than compared to other groups. Reasner et $a l$., has done 44-week study to compare the efficacy and safety of sitagliptin/metformin with metformin monotherapy in type $2 \mathrm{DM}$ treatment-naive patients [15]. It was shown combination had greater reduction than compared to individual drug. Miller S 2006 has shown that sitagliptin as a monotherapy can provide greater reduction of glycemic levels and fewer complications in patients who are intolerant to metformin [16]. Zerilli T, study has shown that there is greater reduction of HBalc with Sitagliptin group and the drug is well tolerated in these groups [17]. In trials, it was that patient treatment with once-daily $100 \mathrm{mg}$ sitagliptin had significantly reduction of $\mathrm{HbA} 1 \mathrm{c}$ when compared with placebo group [18].

\section{CONCLUSION}

Diabetes mellitus is a chronic, progressive disease of epidemic proportions. Because lifestyle modifications alone are often inadequate, two or more agents are usually required to attain adequate glycemic control. The prototype DPP-4 inhibitor, sitagliptin, emerged as the incretin effect became a focus of research. Current guidelines recommend metformin as a first-line therapy for type-2 diabetes. Sitagliptin and metformin provide additive glycemic improvements, suggesting a synergy between the agents. However, although sitagliptin is effective and limited long-term data may restrict its use.

\section{REFERENCES}

1. Miller, S. A., \& St. Onge, E. L. (2006). Sitagliptin: a dipeptidyl peptidase IV inhibitor for the treatment of type 2 diabetes. Annals of Pharmacotherapy, 40(7-8), 1336-1343.

2. Krentz, A. J., \& Bailey, C. J. (2005). Oral antidiabetic agents. Drugs, 65(3), 385-411.

3. Brazg, R., Xu, L., Dalla Man, C., Cobelli, C., Thomas, K., \& Stein, P. P. (2007). Effect of adding sitagliptin, a dipeptidyl peptidase-4 inhibitor, to metformin on 24-h glycaemic control and $\beta$-cell function in patients with type 2 diabetes. Diabetes, Obesity and Metabolism, 9(2), 186-193.

4. Williams-Herman, D., Johnson, J., Teng, R., Golm, G., Kaufman, K. D., Goldstein, B. J., \& Amatruda, J. M. (2010). Efficacy and safety of sitagliptin and metformin as initial combination therapy and as monotherapy over 2 years in patients with type 2 diabetes. Diabetes, Obesity and Metabolism, 12(5), 442-451.

5. Reasner, C., Olansky, L., Seck, T. L., WilliamsHerman, D. E., Chen, M., Terranella, L., ... \& Goldstein, B. J. (2011). The effect of initial therapy with the fixed-dose combination of sitagliptin and metformin compared with metformin monotherapy in patients with type 2 diabetes mellitus. Diabetes, Obesity and Metabolism, 13(7), 644-652.

6. Goldstein, B. J., Feinglos, M. N., Lunceford, J. K., Johnson, J., \& Williams-Herman, D. E. (2007). Effect of initial combination therapy with sitagliptin, a dipeptidyl peptidase-4 inhibitor, and metformin on glycemic control in patients with type 2 diabetes. Diabetes care, 30(8), 1979-1987.

7. Nauck, M. A., Vardarli, I., Deacon, C. F., Holst, J. J., \& Meier, J. J. (2011). Secretion of glucagonlike peptide-1 (GLP-1) in type 2 diabetes: what is up, what is down?. Diabetologia, 54(1), 10-18.

8. Langley, A. K., Suffoletta, T. J., \& Jennings, H. R. (2007). Dipeptidyl peptidase IV inhibitors and the incretin system in type 2 diabetes mellitus. Pharmacotherapy: The Journal of Human Pharmacology and Drug Therapy, 27(8), 1163-1180.

9. Krentz, A. J., \& Bailey, C. J. (2005). Oral antidiabetic agents. Drugs, 65(3), 385-411.

10. Brazg, R., Xu, L., Dalla Man, C., Cobelli, C., Thomas, K., \& Stein, P. P. (2007). Effect of adding sitagliptin, a dipeptidyl peptidase-4 inhibitor, to metformin on 24-h glycaemic control and $\beta$-cell function in patients with type 2 diabetes. Diabetes, Obesity and Metabolism, 9(2), 186-193.

11. Williams-Herman, D., Johnson, J., Teng, R., Golm, G., Kaufman, K. D., Goldstein, B. J., \& Amatruda, J. M. (2010). Efficacy and safety of sitagliptin and metformin as initial combination therapy and as monotherapy over 2 years in patients with type 2 diabetes. Diabetes, Obesity and Metabolism, 12(5), 442-451.

12. Reasner, C., Olansky, L., Seck, T. L., WilliamsHerman, D. E., Chen, M., Terranella, L., ... \& Goldstein, B. J. (2011). The effect of initial therapy with the fixed-dose combination of sitagliptin and metformin compared with metformin monotherapy in patients with type 2 diabetes mellitus. Diabetes, Obesity and Metabolism, 13(7), 644-652.

13. Goldstein, B. J., Feinglos, M. N., Lunceford, J. K., Johnson, J., \& Williams-Herman, D. E. (2007). Effect of initial combination therapy with sitagliptin, a dipeptidyl peptidase-4 inhibitor, and metformin on glycemic control in patients with type 2 diabetes. Diabetes care, 30(8), 1979-1987.

14. Pérez-Monteverde, A., Seck, T., Xu, L., Lee, M. A., Sisk, C. M., Williams-Herman, D. E., ... \& Goldstein, B. J. (2011). Efficacy and safety of sitagliptin and the fixed-dose combination of 
sitagliptin and metformin vs. pioglitazone in drugnaïve patients with type 2 diabetes. International journal of clinical practice, 65(9), 930-938.

15. Miller, S. A., \& St. Onge, E. L. (2006). Sitagliptin: a dipeptidyl peptidase IV inhibitor for the treatment of type 2 diabetes. Annals of Pharmacotherapy, 40(7-8), 1336-1343.

16. Nauck, M. A., Vardarli, I., Deacon, C. F., Holst, J. J., \& Meier, J. J. (2011). Secretion of glucagonlike peptide-1 (GLP-1) in type 2 diabetes: what is up, what is down?. Diabetologia, 54(1), 10-18.

17. Langley, A. K., Suffoletta, T. J., \& Jennings, H. R. (2007). Dipeptidyl peptidase IV inhibitors and the incretin system in type 2 diabetes mellitus. Pharmacotherapy: The Journal of Human Pharmacology and Drug Therapy, 27(8), 1163-1180.

18. Pérez-Monteverde, A., Seck, T., Xu, L., Lee, M. A., Sisk, C. M., Williams-Herman, D. E., ... \& Goldstein, B. J. (2011). Efficacy and safety of sitagliptin and the fixed-dose combination of sitagliptin and metformin vs. pioglitazone in drugnaïve patients with type 2 diabetes. International journal of clinical practice, 65(9), 930-938.

Cite This Article: Naveed Altaf \& Mirza Arshad Asif Baig (2021). Comparative Study to Evaluate Safety and Efficacy of Sitagliptin Versus Metformin Alone and Combination in Type 2 Diabetes Mellitus. EAS J Pharm Pharmacol, 3(2), 5155 